\title{
Optimization of diesel engine dynamics with electronic boost controller
}

JEL: L62 DOI: 10.24136/atest.2019.069

Data zgłoszenia: 15.12.2018 Data akceptacji: 08.02.2019

This paper dals with design of optimized electronic control for diesel engines for all-terrain vehicles. In paper the detailed proposal of control algorithm, as well as procedure for turbocharger innovation is described. Designed optimization algorithm is verified on real Land Rover Defender vehicle. In last part of paper, the measurements on electrodynamic dynamometer are discussed.

\section{Introduction}

Nowadays, rescue forces use long time verified and reliable technology of all-terrain vehicles of well-known manufacturer Land Rover. The Land Rover Defender model is still most used due to very good off-road capabilities. In these vehicles many types of diesel engines are used, mostly the popular TD4 (which is on the other side obsolete) and newer TD5 version P15. Rescue forces uses special equipment (for example electric winch, lights and other tools) for their purposes, this equipment increase vehicle weight. Together with specific driving profile in off road conditions, the requirements of rescue forces on diesel engine dynamics, differs from requirements of normal user. Due to above mentioned reasons, the default diesel engine cannot fulfill these requirements. Proposed optimization of control algorithm and turbocharger increases power and torque of diesel engine, which results in better vehicle dynamics especially at lower engine speed. Proposed mechanical part of optimization consists from replacement of original Land Rover turbocharger for new modern variable nozzle turbocharger (VNT). Electronic part of optimization is based on completely new control algorithm of boost pressure. This control algorithm is implemented in special electronic turbocharger control unit (ETCU). Detailed description is mentioned in next chapters.

\section{Mechanical optimization}

The diesel P15 engines have maximal power $130 \mathrm{HP}$ and maximal torque starts from 2200 RPM. For driving fully equipped vehicle in off-road and forest conditions, the power and power - torque curve of default engine is not sufficient. The insufficient dynamics of vehicle during the gears shifting and the long turbocharger lag degrades the great terrain capabilities of chassis and transmission mechanics of the vehicle.

Technical parameters of default engine:

- 15P engine code

- 5 - cylinder in-line engine

- Compression ratio 19.5/1

- Fuel injection: Lucas MEMS 3 unitary pumps

- Boost induction: Turbocharger GT20

- Maximal power $88 \mathrm{~kW}$

- Maximal torque $300 \mathrm{Nm}$

The used default turbocharger (GT20 with wastegate filling pressure regulation) is necessary to replace with new VNT turbocharger during the engine modification. The internal part of replaced turbocharger consists of modern VNT1756 turbine with variable nozzle regulation mechanism and with control of VNT mechanism through servo-drive unit (REA). The main advantage of this modification is in possibility of modification of boost pressure through ETCU in dependence of driving profile. New turbocharger allows to achieve maximal boost pressure at lower RPM (500 RPM less than old turbocharger). After optimization of turbocharger, the throttle response is significantly faster, so the dynamical response of vehicle is more suitable for use in off-road conditions.

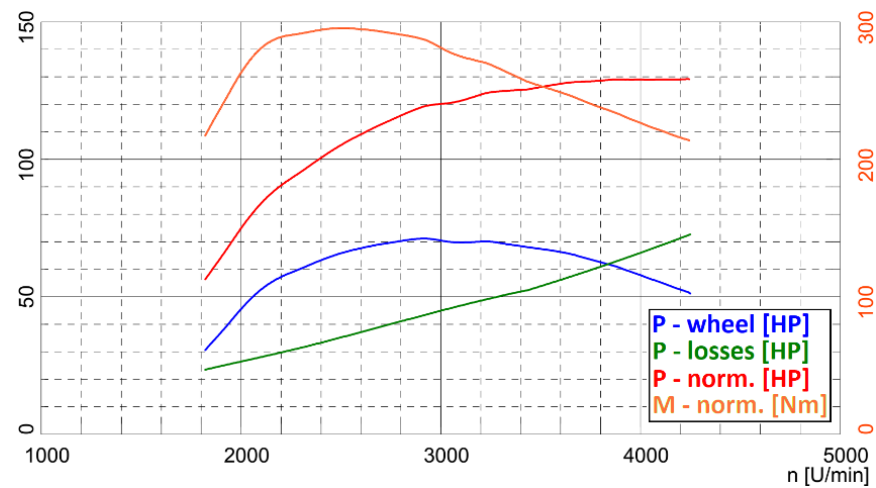

Fig. 1 Dynamical parameters of default turbocharger

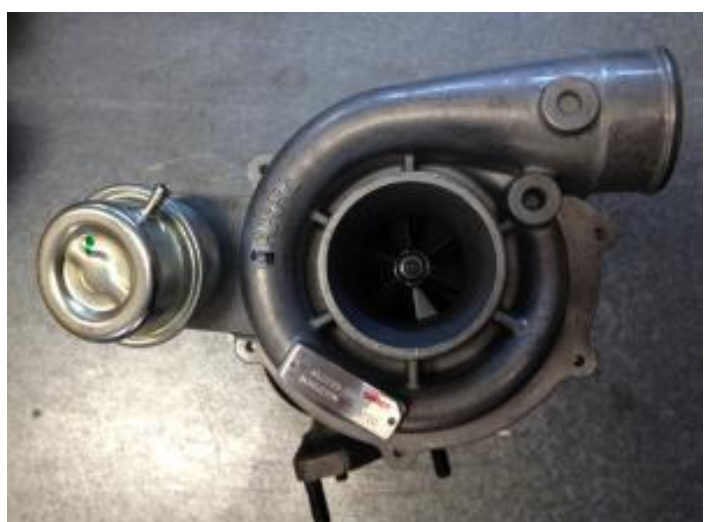

Fig. 2 Factory original Land Rover turbocharger

The installation procedure of new turbocharger is not difficult but is necessary to add custom mage mount between exhaust manifold and new turbocharger housing. For correct function of new mounted turbocharger, the connection of new control unit is necessary, since the MEMS3 control system does not support algorithm to control VNT turbochargers with electronic REA regulation. [1,2,3]

\section{Optimization of control system}

The most important part of the proposed optimization is new control system with modified control algorithm of turbocharger function. The main part of proposed control system is 16-bit dual-core MCU Freescale MCS9S12 clocked on $50 \mathrm{MHz}$. 


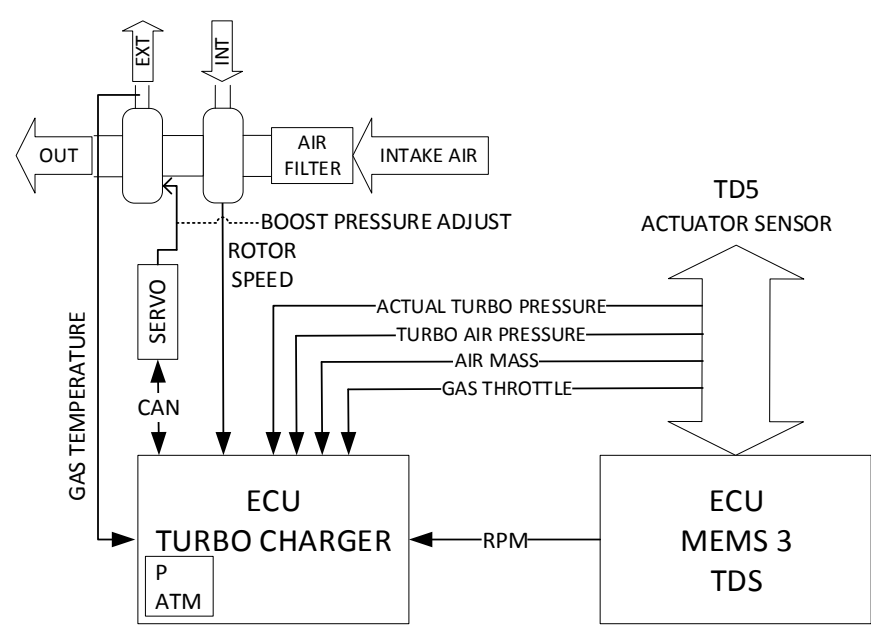

Fig. 3 Implementation of optimized control system

The control system uses discrete PSD controller with preprogrammed look-up tables and real time calculations to regulate the boost pressure. This functionality is not installed in MEMS3 control system, therefore the installation of new specialized electronic turbocharger control unit (ETCU) is necessary. This control unit is connected parallel to ECU MEMS3 and uses existing sensor signals to compute of boost pressure value, position of VNT turbocharger and self-diagnostics of system.

The new proposed control system can by separated to three main building blocks - fig. 3 :

The first block is intended to analog values/signals acquisition and processing. Main part of this block is analog to digital converter with implemented software filters.

The second block - computation block computes reference turbocharger boost pressure, which is predefined in look-up tables. This block also adjusts correction values of basic look-up table in dependency on the atmospheric pressure and temperature of the intake pressure.

The third block - PSD controller is part of the computation block. The structure of PSD controller allows the precise regulation of boost pressure. The output from specialized PSD controller controls the servo drive unit (REA), which controls the VNT turbocharger over the CAN bus.

Diagnostic block - important part of proposed system which monitors the right functionality of all system components. This block also can detect stuck VNT mechanism, blocked or destructed filling pressure hose or overrun of regulating current of turbocharger. All working parameters are predefined in mathematical behavioral model of the engine. This mathematical model is implemented in ETCU.

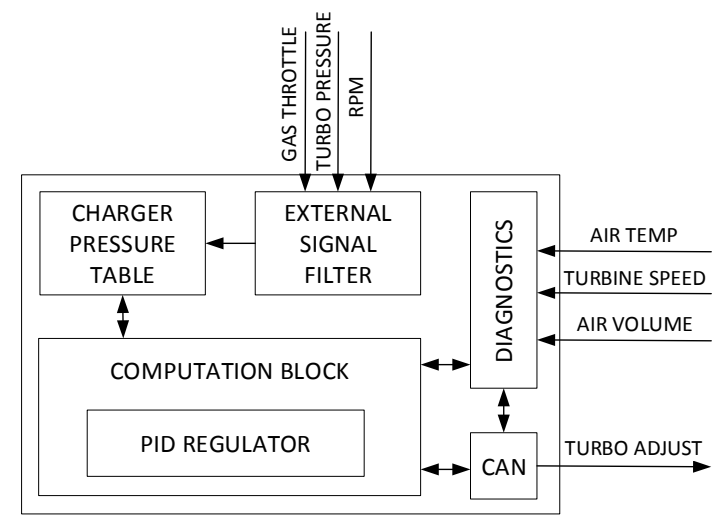

TURBO CHARGER ECU

Fig. 4 Block diagram of proposed control system implemented in electronic turbocharger control unit

\section{Measurements of optimized engine}

The engine torque and power measurements are realized after modification and basic setting of the new turbocharger system in vehicle on the MAHA LPS 3000 dynamometer. The engine horse power and torque results after modification are comparable with modern produced vehicles. The emission standards and classes of modified vehicle are not changed after modification. [5]

Technical parameters of optimized engine:

- Compression ratio 19.5/1

- Fuel injection: Lucas MEMS3 + boost controller + BH motorsport remap

- Boost induction: turbocharger VNT1756

- Max power $158 \mathrm{~kW},(3850 \mathrm{RPM})$

- Max torque: 464 Nm, 400 Nm (1700 - 3800 RPM)

The increase of engine horse power after modification is $70 \mathrm{~kW}$, see fig. 4. This increase offers better driving dynamics and maneuverability of the vehicle in the terrain conditions and in mountain conditions. The accelerator pedal can easily control the engine power and after optimization quick engine response is achieved. The volume of solid particles in exhaust gases is lower after optimization of turbocharger and control system. This fact is caused by the modern construction of VNT turbocharger and optimized control algorithm for specific use.

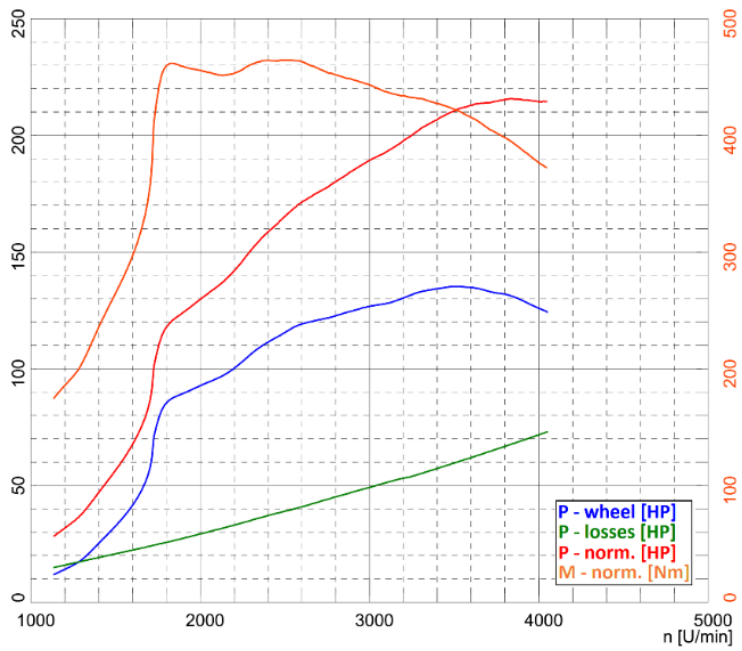

Fig. 5 Dynamical parameters of optimized engine

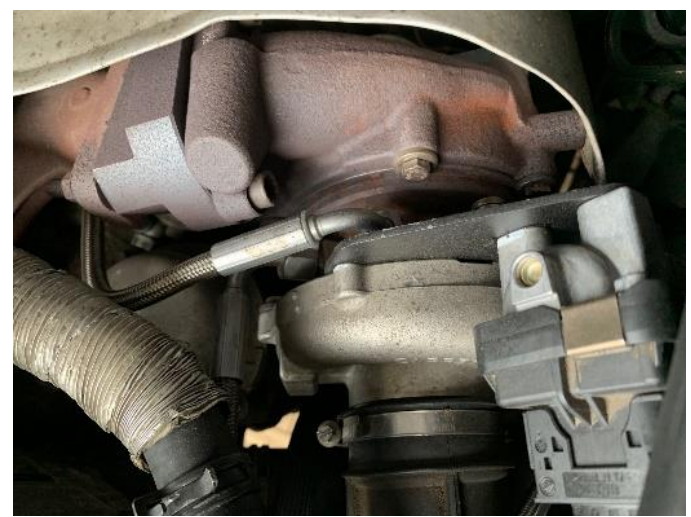

Fig. 6 Picture of new VNT turbocharger

Comparison of optimized and default turbocharger/diesel engine is shown on fig. 5. From fig. 5 is clear, that slope of optimized engine torque is at $1800 \mathrm{rpm}(464 \mathrm{Nm})$, while the maximum torque of non-optimized engine is at $2200 \mathrm{rpm}(300 \mathrm{Nm})$. Maximum value of power is increased by $55 \mathrm{~kW}$ and operating range is $1700-3800$ rpm ( $80 \%$ of maximum torque). In default diesel engine, the $80 \%$ of 
maximum torque is available from $2000-3500 \mathrm{rpm}$. Thanks to use of optimized control system, the modified diesel engine works still in safe operating limits.

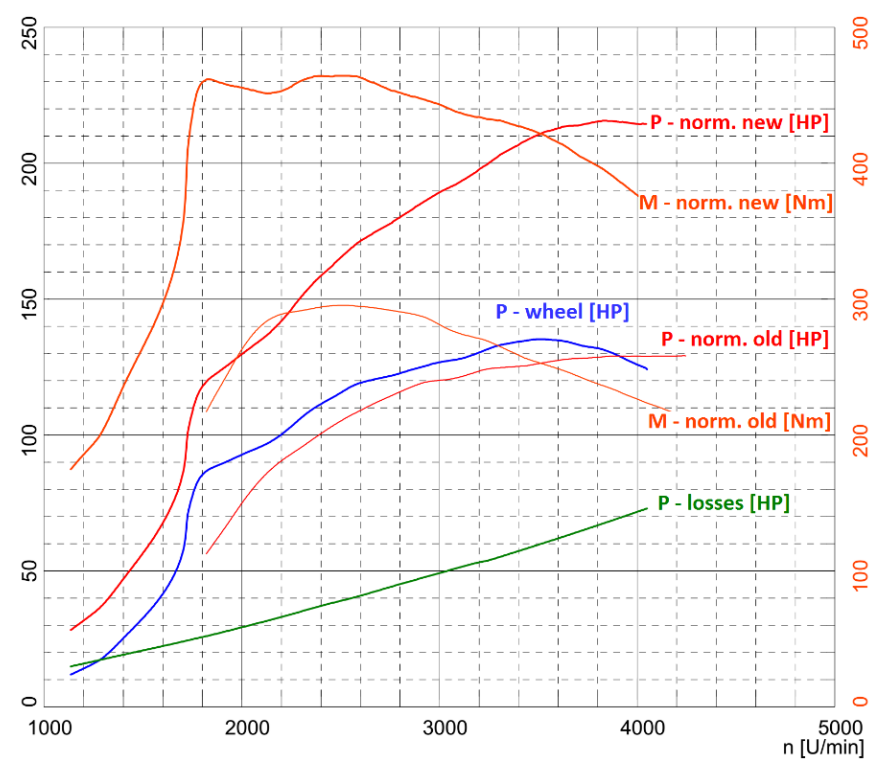

Fig. 7 Comparison of optimized and default diesel engine dynamics

\section{CONCLUSION}

In this article, the optimized turbocharger control for TD5 diesel was proposed. The primary purpose was modification of default Land Rover engine (with excellent features), for the use in special conditions and with special equipment. The described modification was implemented in 2017 and was subjected to a real-time test in 2018. During the test the consumption, driving characteristics and overall dynamics were checked. By modifying and installing the optimized ETCU, a reduction in solid particulate matter during vehicle acceleration (17-20\%) has been achieved with a reduction in consumption (off-road use) of approximately 0.7-1 liter per hour. During the rotating parts of the turbocharger inspection, no deficiencies which can reduce the life of the engine have been identified. Current research is focused on the automatic adaptability of proposed system according to the actual use of the vehicle.

\section{Acknowledgement}

The authors wish to thanks to company BH Motorsport for help during research, development and measurements of optimized diesel engine. This work was supported by project APVV-15-0571
Research of the optimum energy flow control in the electric vehicle system.

\section{Bibliography}

1. Kiencke U., Nielsen L., Automotive Control Systems for engine, driveline and vehicle, Second Edition, ISBN 978-3-540-23139-4, Springer 2005

2. Robert Bosch $\mathrm{GmbH}$, Bosch Automotive Electrics and Automotive Electronics, 5th Edition, ISBN 978-3-658-01784-2

3. Ribbens W. B., Understanding Automotive Electronics, 8th edition, ISBN 978-0-12-810434-7, Butterworth-heinemann 2017

4. Erjavec J., Thompson R., Automotive Technology a system approach, 6th Edition, ISBN 978-1-133-61231-5

5. Dobrucký B., Drgoňa P., Hanko B., Electric servosystem for turbocharger vacuum actuator replacement, Autobusy 6/2017

\section{Optymalizacja dynamiki silnika diesla z elektronicznym regulatorem boost}

Niniejszy dokument przedstawia projekt zoptymalizowanego sterowania elektronicznego dla silników wysokoprężnych do pojazdów terenowych. W pracy opisano szczegółowa propozycję algorytmu sterowania, a także procedurę dotyczącą innowacji turbosprężarki. Zaprojektowany algorytm optymalizacyjny jest weryfikowany na prawdziwym pojeździe Land Rover Defender. W ostatniej części artykułu omówiono pomiary elektrodynamicznego dyna-miometru.

\section{Authors:}

Prof. Branislav Dobrucký - the University of Žilina - Department of Mechatronics and Electronics. He graduated from the University of Žilina in the field of Electrical Traction and Energetics. Email: branislav.dobrucky@fel.uniza.sk.

Assoc. Prof. Peter Drgoňa - the University of Žilina - Head of Department of Mechatronics and Electronics. He graduated from the University of Žilina in the field of Power Electronic System. E-mail: peter.drgona@fel.uniza.sk

Ing. Branislav Hanko - the University of Žilina - PhD. Student. He graduated from the University of Žilina in the field of Power Electronic Systems. E-mail: branislav.hanko@fel.uniza.sk

Ing. Ján Morgoš - the University of Žilina - PhD. Student. He graduated from the University of Žilina in the field of Power Electronic Systems. E-mail: jan morgos@fel.uniza.sk 